US Army Corps of Engineers

Engineer Research and Development Center

Effects of Fog Oil Smoke on Immune Responses in the House Sparrow (Passer domesticus) and Red-winged Blackbird (Agelaius phoeniceus)

Crystal Driver, Anne Jarrell, Jennifer Ollero, Brett Tiller, Robert Fulton, Gary Dennis, Harold E. Balbach, and Keturah Reinbold

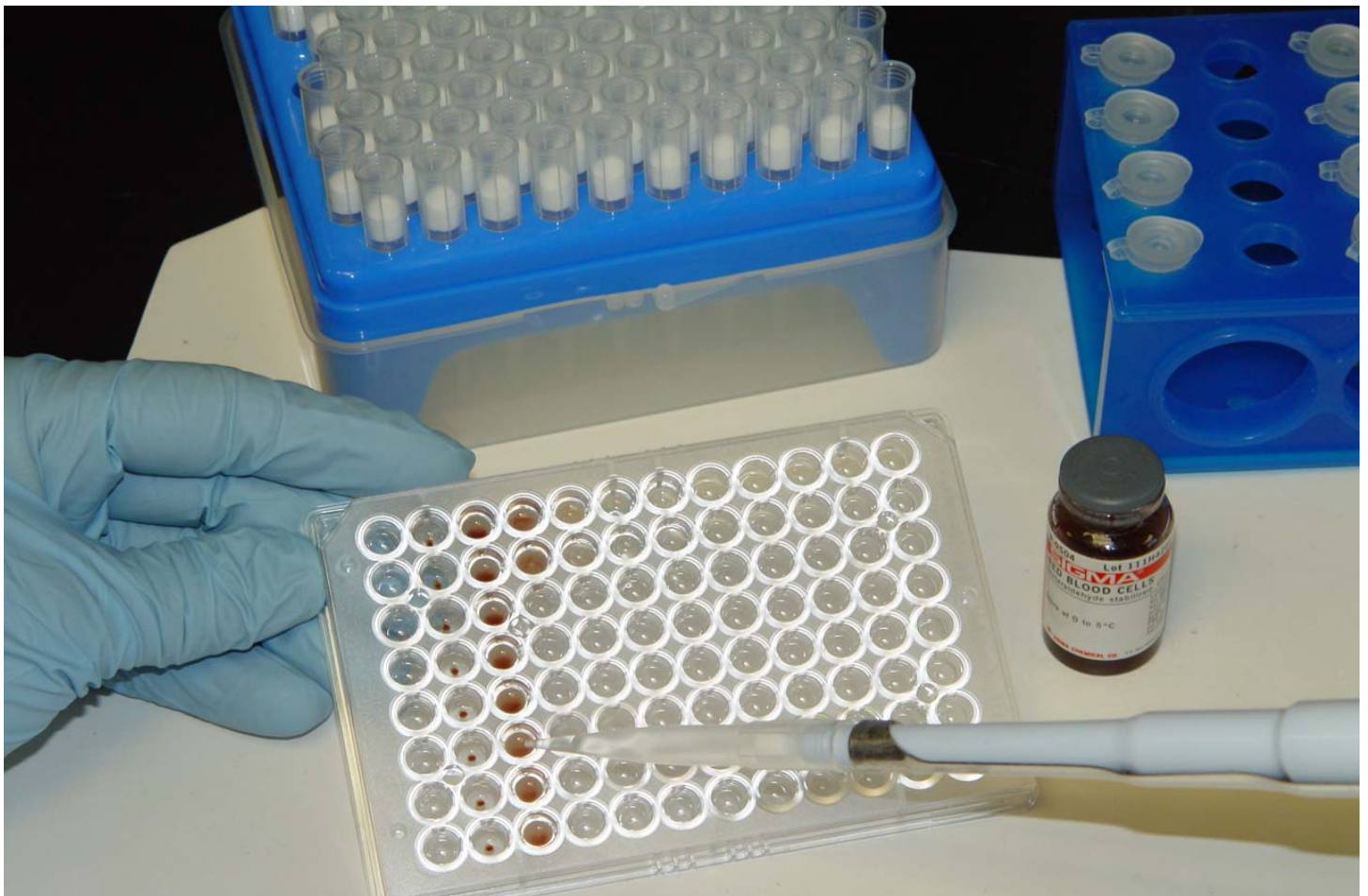




\section{Effects of Fog Oil Smoke on Immune Responses in the House Sparrow (Passer domesticus) and Red-winged Blackbird (Agelaius phoeniceus)}

Crystal Driver, Anne Jarrell, Jennifer Ollero, Brett Tiller, Robert Fulton, and Gary Dennis Pacific Northwest National Laboratory P.O. Box 999

902 Batelle Boulevard

Richland, Washington 99352

Harold E. Balbach and Keturah Reinbold

Construction Engineering Research Laboratory

PO Box 9005

Champaign, IL 61826-9005

Final Report

Approved for public release; distribution is unlimited.

Prepared for Strategic Environmental Research and Development Program Arlington, VA 22203-1821 
ABSTRACT: In response to questions about the effects of military use of fog oil (FO) obscurant smoke, the sensitivity of cell-mediated constituents of the immune system to FO smoke was tested using an avianpox challenge in red-winged blackbirds. Although immunosuppression has been observed in seabirds that have ingested petrochemicals, the immune response in blackbirds exposed to airborne FO was not compromised. The incidence and severity of disease was somewhat less and recovery more advanced in the FO-exposed blackbirds than in controls. Circulating antibody titers to sheep red blood cells were measured in house sparrows by hemagglutination titration. No differences in total, 2mercaptoethanol-sensitive, or 2-mercaptoethanol-resistant antibody titers were observed, suggesting that humoral immunity is also unaffected by high field-typical FO exposure. Total and differential white blood cell counts were not depressed and spleen mass and structure were not affected in any of the birds exposed to the airborne FO, further indicating that the smoke did not compromise the nonspecific immune function of the birds. No FO-induced mortality, organ pathology, or end point metabolites were observed in either passerine species. These data indicate that the use of FO at normal field concentrations is unlikely to result in decreased immunological fitness of exposed birds.

DISCLAIMER: The contents of this report are not to be used for advertising, publication, or promotional purposes.

Citation of trade names does not constitute an official endorsement or approval of the use of such commercial products.

All product names and trademarks cited are the property of their respective owners. The findings of this report are not to be construed as an official Department of the Army position unless so designated by other authorized documents.

DESTROY THIS REPORT WHEN IT IS NO LONGER NEEDED. DO NOT RETURN IT TO THE ORIGINATOR. 


\section{Pacific Northwest National Laboratory}

Operated by Battelle for the U.S. Department of Energy

This report was prepared as an account of work sponsored by an agency of the United States Government. Neither the United States Government nor any agency thereof, nor Battelle Memorial Institute, nor any of their employees, makes any warranty, express or implied, or assumes any legal liability or responsibility for accuracy, completeness, or usefulness of any information, apparatus, product, or process disclosed, or represents that its use would not infringe privately owned rights. Reference herein to any specific commercial product, process, or service by trade name, trademark, manufacturer, or otherwise does not necessarily constitute or imply its endorsement, recommendation, or favoring by the United States Government or any agency thereof, or Battelle Memorial Institute. The views and opinions of authors expressed herein do not necessarily state or reflect those of the United States Government or any agency thereof.

Prepared for the U.S. Department of Energy under a related services contract for the Engineer Research and Development Center/Construction Engineering Research Laboratory under contract DE-AC06-76RL01830. 


\section{Contents}

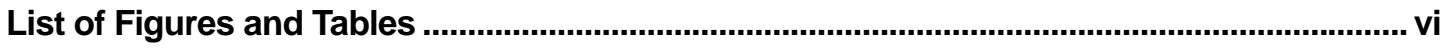

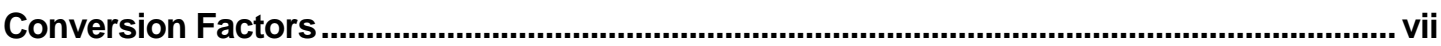

Preface

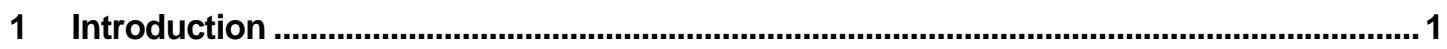

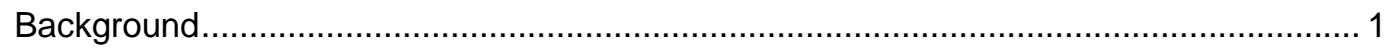

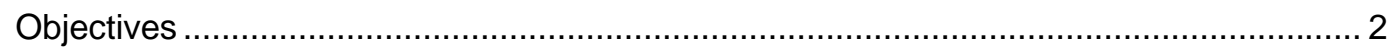

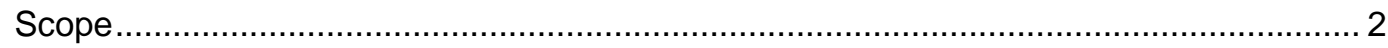

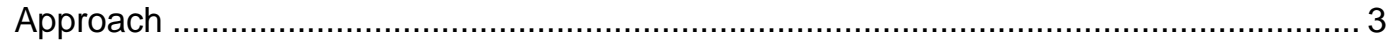

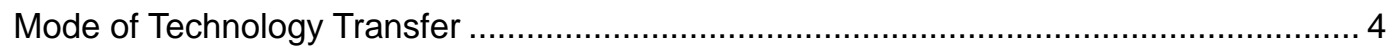

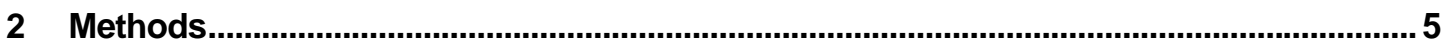

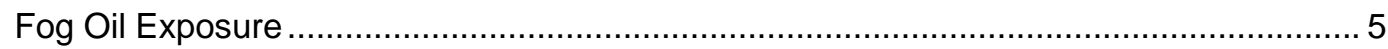

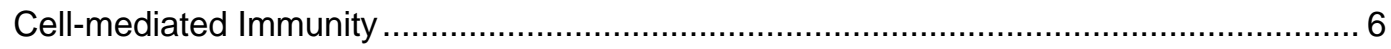

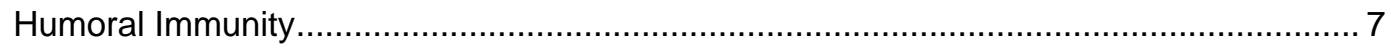

Mortality and Clinical Signs of Toxicity and/or Stress ................................................. 8

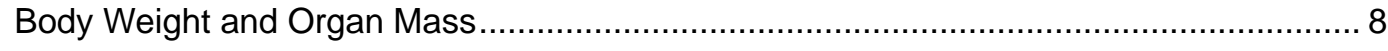

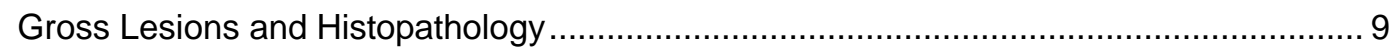

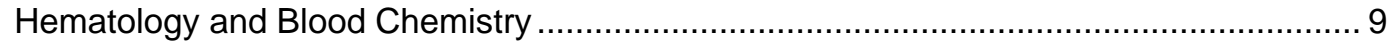

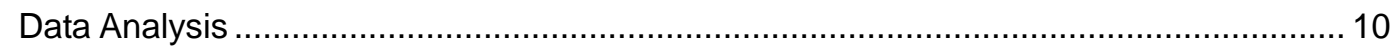

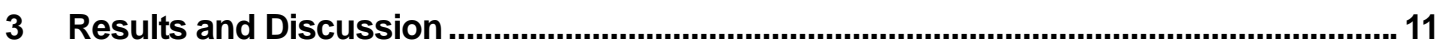

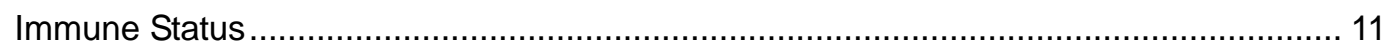

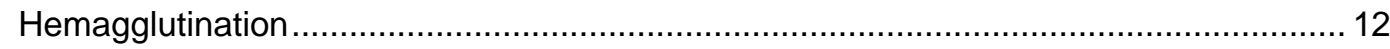

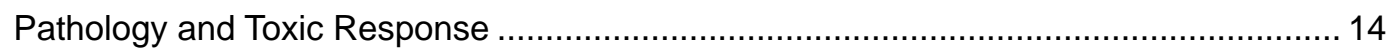

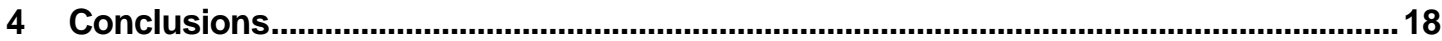

References

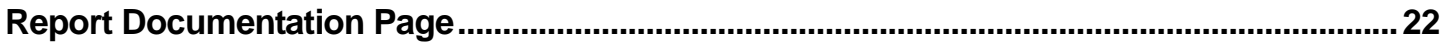




\section{List of Figures and Tables}

\section{Figures}

1. Evaluating the effect of fog oil on humoral immunity in house sparrows.

2. Body mass (in grams) of female red-winged blackbirds exposed to fog oil smoke and avianpox

\section{Tables}

1. Body condition and incidence of histopathologic lesions in red-winged blackbirds exposed to fog oil smoke

2. Total and differential white blood cell counts for adult female red-winged blackbirds exposed to fog oil smoke

3. Total, 2-Mercaptoethanol-sensitive (IgM), and 2-Mercaptoethanol-resistant (IgG) antibody titers in house sparrows at 7 days after primary immunization with sheep red blood cells.....

4. Total and differential white blood cell counts for house sparrows exposed to fog oil smoke

5. Blood chemistry of female red-winged blackbirds exposed to fog oil smoke

6. Body condition, body weights and organ mass of house sparrows exposed to fog oil smoke.....

7. Organ weights (as percentage of body weight) of red-winged blackbirds exposed to fog oil smoke 16

8. Histopathologic lesions in house sparrows exposed to fog oil smoke 


\section{Conversion Factors}

Non-SI* units of measurement used in this report can be converted to SI units as follows:

\begin{tabular}{|c|c|c|}
\hline Multiply & By & To Obtain \\
\hline acres & $4,046.873$ & square meters \\
\hline cubic feet & 0.02831685 & cubic meters \\
\hline cubic inches & 0.00001638706 & cubic meters \\
\hline degrees (angle) & 0.01745329 & radians \\
\hline degrees Fahrenheit & $(5 / 9) \times\left({ }^{\circ} \mathrm{F}-32\right)$ & degrees Celsius \\
\hline degrees Fahrenheit & $(5 / 9) \times\left({ }^{\circ} \mathrm{F}-32\right)+273.15$ & kelvins \\
\hline feet & 0.3048 & meters \\
\hline gallons (U.S. liquid) & 0.003785412 & cubic meters \\
\hline horsepower (550 ft-lb force per second) & 745.6999 & watts \\
\hline inches & 0.0254 & meters \\
\hline kips per square foot & 47.88026 & kilopascals \\
\hline kips per square inch & 6.894757 & megapascals \\
\hline miles (U.S. statute) & 1.609347 & kilometers \\
\hline pounds (force) & 4.448222 & newtons \\
\hline pounds (force) per square inch & 0.006894757 & megapascals \\
\hline pounds (mass) & 0.4535924 & kilograms \\
\hline square feet & 0.09290304 & square meters \\
\hline square miles & $2,589,998$ & square meters \\
\hline tons (force) & $8,896.443$ & newtons \\
\hline tons $(2,000$ pounds, mass $)$ & 907.1847 & kilograms \\
\hline yards & 0.9144 & meters \\
\hline
\end{tabular}

\footnotetext{
*Système International d'Unités ("International System of Measurement"), commonly known as the "metric system."
} 


\section{Preface}

This study was conducted for the Strategic Environmental Research and Development Program (SERDP) under project CS-507, "Threatened, Endangered, and Sensitive Resources: Impact of Smokes and Obscurants on TES." The technical monitor for the project was Dr. Femi A. Ayorinde, SERDP Cleanup and Conservation Program Manager, followed by Dr. Robert W. Holst, Compliance and Conservation Program Manager. The Executive Director of SERDP is Mr. Bradley P. Smith.

The work was completed under the direction of the Ecological Processes Branch (CN-N) of the Installations Division (CN), Construction Engineering Research Laboratory (CERL). The CERL Principal Investigator and contract monitor was Dr. Keturah Reinbold. Dr. Harold E. Balbach assumed responsibility as Principal Investigator following Dr. Reinbold's retirement. The work was performed by the Pacific Northwest National Laboratory (PNNL), Richland, Washington. Crystal Driver was the PNNL Principal Investigator. The work was completed under Military Interdepartmental Purchase Requests (MIPRs) W52EU261647000, W52EU28254173, and W2V5aa51305044. Patricia M. Kirby, Colorado State University contractor, coordinated preparation of the final report. The technical editor was Gloria J. Wienke, Information Technology Laboratory. Steve Hodapp is Chief, CEERD-CN-N, and Dr. John T. Bandy is Chief, CEERD-CN. The associated Technical Director was Dr. William D. Severinghaus, CEERD-CV-T. The Director of CERL is Dr. Alan W. Moore.

CERL is an element of the U.S. Army Engineer Research and Development Center (ERDC), U.S. Army Corps of Engineers. The Commander and Executive Director of ERDC is COL James R. Rowan, and the Director of ERDC is Dr. James R. Houston. 


\section{Introduction}

\section{Background}

There is increasing evidence that environmental contaminants can alter physiological systems that resist infection in vertebrates (Kerkvliet et al. 1982, Fairbrother and Fowles 1990, Schuurman et al. 1991). Further, alteration of the immune response can occur at concentrations well below those causing overt signs of toxicity and the adverse effects of immunotoxic agents may persist long after other effects can be detected (Kerkvleit et al. 1982). Crude oil and petroleum distillates are among those chemicals that have been implicated in immune system dysfunction in birds (Briggs, Yoshida, and Gershwin 1996; Rocke, Yuill, and Hinsdill 1984). In laboratory experiments, ingestion of petroleum distillates has been shown to reduce the phagocytic and cytotoxic capacity of monocytes and heterophils in waterfowl (Rocke, Yuill, and Hinsdill 1984) and to target cell-mediated components of the immune system rather than the antibody-mediated mechanisms (Goldberg, Yuill, and Burgess 1990; Arstila, Vainio, and Lassila 1994). Depressed leukocyte numbers in the circulation and in the major lymphoid organs (spleen and bursa of Fabricius) has been observed in oiled seabirds. This depression in white blood cells (WBC) is often accompanied by an adaptive shift in the bone marrow from white cell to red cell production, probably in response to petroleum-induced hemolytic anemia (Holmes, Gorsline, and Cronshaw 1979; Leighton 1986; McOrist and Lenghaus 1992; White 1992). The high incidence of viral, fungal, and bacterial diseases reported for a wide variety of seabirds recovering from oil spill exposure underscores the immunosuppressive potential of petrochemicals (Croxall 1977, McOrist and Lenghaus 1992, White 1992, Burger and Fry 1993). Increased incidence of death and disease in a population can have serious consequences for endangered species. Particularly susceptible populations may be those of semi-colonial and colonial species such as the red-cockaded woodpecker (Picoides borealis) whose gregarious habit potentially facilitates the spread of pathogens.

Fog oil is a petroleum product used to generate obscurant smoke for troop preparedness training. Obscurant smoke is used to mask movements of troops and mechanized equipment. SGF-2 fog oil (FO) is the obscurant most often used for military training because of its low cost, ease of handling and smoke generation, dispersion characteristics, and safety (Eberhard, Cupp, and Abshire 1989). It is a middle distillate product of crude petroleum and is drawn from raw industrial lubricant oil. 
cant oil. FO procured by the United States military has undergone a modified refining process to reduce quantities of potentially harmful components. Although called a "smoke" because of its appearance when generated in the field, it is not burned, but rather vaporized and disseminated by re-condensation as the vapors cool in the air. Airborne FO droplets have a mass median aerodynamic diameter (MMAD) typically between 0.9 and $1.9 \mu \mathrm{m}$ (Driver et al. 1993), a size range that deposits within the lung and air sacs of birds (Driver et al. 1990).

Originally, the use of fog oil in areas inhabited by threatened and endangered species such as the red-cockaded woodpecker (RCW) raised the question of the potential for injury to that species. To address these concerns, a series of studies, of which this is the third, has been conducted with funding from the Department of Defense Strategic Environmental Research and Development Program (SERDP). The first two studies examined acute inhalation toxicity (Driver et al. 2002a) and effects on eggs and nestlings (Driver et al. 2002b). No significant adverse effects were found in either study. In both cases, altricial, passerine body weight surrogates for the endangered RCW were used.

In addition to the potential for petroleum products such as fog oil to cause debilitating effects to the organs and general health of birds, the question has been raised as to the potential to impair the immune response in birds. Altered immune response may lead to rapid transmittal of pathogens among the familial clans maintained by species such as the RCW; therefore it is important that the immunotoxic effects of fog oil aerosols be evaluated in wild birds.

\section{Objectives}

The objectives of this series of studies were to evaluate the health effects of fog oil aerosols in various species surrogates for the red-cockaded woodpecker, and to provide information for general and site-specific risk assessments and the management of obscurant fog oil generations and training activities. The objective of the current study was to evaluate the effects of whole body exposure to fog oil aerosols on immune response of wild birds.

\section{Scope}

The studies described in this report are limited to selected, but representative immune system responses common to vertebrates. Studies were conducted on preadult and adult surrogate species; no individuals of any threatened or endangered species were utilized. Previous reports on the effects of fog oil smoke examined 
acute inhalation toxicity and effects on eggs, hatchlings and nestlings. The studies in this series did not attempt to identify the toxicity of fog oil, but rather its effects at concentrations relevant to its use by the Army under normal field conditions.

\section{Approach}

House sparrows (Passer domesticus) and red-winged blackbirds (Agelaius phoeniceus) were trapped in Benton and Franklin Counties, Washington, and maintained in an outdoor aviary at Pacific Northwest National Laboratory (PNNL). Birds were assigned to test groups using a random numbers generator. Prior to fog oil exposure, birds were transferred to the Aerosol Research Facility at PNNL where they were exposed to FO smoke at concentrations between 300 and $450 \mathrm{mg} / \mathrm{m}^{3}$, a range representative of high, near-source field concentrations. Control birds were transferred and held in the exposure chambers but not exposed to the smoke. Birds were exposed daily for 1 hour for 4 consecutive days. Test concentrations for the blackbirds averaged $300 \mathrm{mg} / \mathrm{m}^{3}$. Mean test concentration during the sparrow exposures was $435 \mathrm{mg} / \mathrm{m}^{3}$.

To assess cell-mediated immunity response, immature blackbirds presenting no pox symptoms were housed with adult blackbirds that were symptomatic for avianpox. When $10 \%$ of the immature birds showed pox lesions, the blackbirds were exposed to FO smoke. Following necropsy, the number of birds exhibiting gross or histological pox lesions was recorded.

Humoral immunity and functional integrity/capacity of major organs were also assessed. To assess humoral immunity, house sparrows were sensitized to sheep red blood cells, and exposed to FO smoke. Antibody response of these birds was compared to the non-immunized control and FO exposed birds. To assess the functional integrity/capacity of the major organs, several metabolic end points were measured including calcium, cholesterol, glucose, total protein, albumin, globulin, and uric acid. Cholesterol, glucose, and uric acid were analyzed enzymatically using microbial cholesterol esterase, heoxokinase, and uricase, respectively.

Throughout the study, birds were visually observed for clinical signs of toxicity and/or stress, and mortality. At necropsy, all major organs were examined for gross lesions, and tissues were submitted for reading by a veterinary pathologist. As measures of stress and the impact of fog oil on immune response, leucocyte numbers and morphology in peripheral blood were examined. 


\section{Mode of Technology Transfer}

The information included in this report is one portion of the materials prepared by the Engineer Research and Development Center (ERDC) to assist installation natural resources and threatened and endangered species program managers. The primary means of communicating the immunotoxicity information will be through publication in the scientific literature, as well as through the availability of this report. The specific data presented are intended to be used in the preparation of biological opinions related to planned Army actions where the red-cockaded woodpecker (or other similar avian species) is present, and for endangered species management plans (ESMPs), integrated natural resources management plans (INRMPs), and in the preparation of ecological risk assessments involving fog oil smoke and avian species.

This report will be made accessible through the World Wide Web (WWW) at URL: http://www.cecer.army.mil 


\section{Methods}

House sparrows (Passer domesticus) and red-winged blackbirds (Agelaius phoeniceus) were trapped in Benton and Franklin Counties, Washington, and maintained in an outdoor aviary at Pacific Northwest National Laboratory (PNNL). Note that these are the same two surrogate species that were used in the first two studies (Driver et al. 2002 a,b). The birds did not occupy the aviary at the same time. One-third of the $9.1 \mathrm{~m}$ wide by $15.2 \mathrm{~m}$ long by $3.7 \mathrm{~m}$ high ( $30 \mathrm{ft}$ by $50 \mathrm{ft}$ by 12 $\mathrm{ft}$ ) aviary was covered by a metal roof. Deciduous and evergreen trees and shrubs as well as artificial roost boxes were provided for additional shelter. Both species were fed a pelleted complete diet for soft-billed passerines (Ziegler Bros., Inc., Gardners, PA) and provided tap water ad libitum. Each bird was identified by a uniquely numbered leg band. Birds were assigned to test groups using a random numbers generator (Microsoft@ Excel).

The birds in this study were maintained outdoors and were subject to field typical weather fluctuations. Sparrows were exposed to the obscurant aerosols in the fall and experienced temperatures ranging from near freezing to $85^{\circ} \mathrm{F}$. Relative humidity ranged from $27 \%$ to raining during this period. The exposures of the red-winged blackbirds occurred during late fall and winter. Temperatures to which they were exposed ranged from below freezing to $83^{\circ} \mathrm{F}$.

\section{Fog Oil Exposure}

Birds were transferred to the Aerosol Research Facility at PNNL and exposed to FO smoke at concentrations between 300 and $450 \mathrm{mg} / \mathrm{m}^{3}$. This concentration range is representative of high, near-source field concentrations based on predictions from a modified Gaussian plume dispersion model (Driver et al. 1993). Control birds were similarly transferred and held in the exposure chambers but were not exposed to the smoke. Birds were exposed daily for 1 hour for 4 consecutive days. FO generation and chamber conditions were described previously (Driver et al. 2002a). Test conditions and aerosol characteristics were monitored and analyzed during the exposure tests. The mass median diameter of the FO aerosol was $1.2 \mu \mathrm{m}$ with a GSD (geometric standard deviation) of 1.7. Test concentrations for the blackbirds averaged $300 \mathrm{mg} / \mathrm{m}^{3}$. Mean test concentration during the sparrow exposures was $435 \mathrm{mg} / \mathrm{m}^{3}$. 


\section{Cell-mediated Immunity}

A key method for assessing immune system competence is to monitor in vivo responses to direct challenge with known pathogens. This type of study has only rarely been conducted with petrochemical contaminants and only for the oral route of exposure (i.e., by ingestion) and only in sea birds (Rocke, Yuill, and Hinsdill 1984; Briggs, Gershwin, and Anderson 1997). Recent reviews indicate that petroleum distillates appear to target the cell-mediated mechanisms of the immune system rather than humoral components (Briggs, Yoshida, and Gershwin 1996; Briggs, Gershwin, and Anderson 1997). To estimate the impact of FO aerosols on immune function in a species such as the red-cockaded woodpecker, we exposed a passerine species (redwinged blackbird) to a common pathogen, avianpox, that is mitigated by cellular mechanisms.

Wild-caught young-of-the-year blackbirds presenting no pox symptoms were housed for two weeks with adult blackbirds that were symptomatic for avianpox. Infection with avianpox was used because host recovery is primarily a function of cellmediated immunity with minimal, if any, production of antibodies (Ritchie, Harrison, and Harrison 1994). When $10 \%$ of the immature birds showed pox lesions, the blackbirds were exposed to $300 \mathrm{mg} / \mathrm{m}^{3}$ of $\mathrm{FO}$ smoke for 1 hour per day for 4 consecutive days. Control birds were handled in a manner similar to the FO-treated birds but without exposure to FO. The birds were then observed for 40 days, euthanized with $\mathrm{CO}_{2}$ and necropsied. The number of birds exhibiting gross or histological pox lesions was recorded for the controls and treated birds.

Cytologic examination of the peripheral blood was performed at necropsy. Blood smears were obtained immediately following blood collection to preserve cell morphology and were made using a standard 2-slide wedge technique. Blood smears were stained with Wright-Giemsa for differential white cell counts. Total white cell counts were performed using Natt-Herricks's stain with a hemocytometer. Cells were stained and classified according to Dein (1984).

Hemolytic, regenerative anemia is well documented in birds exposed to petroleum through ingestion (Leighton 1986) and is associated with an adaptive shift from white cell to red cell production. To examine subjects for any such effects, erythrocyte morphology and packed cell volume (PCV) were measured in the blackbirds to determine incidence of anemia among treated birds and the ability of the bone marrow to respond to the anemic state. Cell morphology was evaluated for signs of toxicity (polychromasia, presence of immature erythrocytes, variations in nucleus location and shape, cytoplasmic basophilic stippling and agglutination). The degree of toxicity was ranked on a scale of +1 (slight damage) to +4 (severe damage). PCV 
was obtained for blackbirds by centrifugation of blood-filled microhematocrit tubes at $12,000 \mathrm{~g}$ (standard acceleration of gravity) for 5 minutes. PCV was not determined for the house sparrows.

Because the spleen is involved in rapid humoral and cellular response to antigens, spleen weights were obtained at necropsy and splenic tissue examined histologically for lymphocyte number.

\section{Humoral Immunity}

Primary hemagglutinating antibody responses were evaluated using the procedure described by Tsiagbe et al. (1987). Twenty eight house sparrows (14 immunizedcontrols and 14 birds exposed to $435 \mathrm{mg} / \mathrm{m}^{3}$ of FO) were sensitized to sheep erythrocytes (sheep red blood cells [SRBC]) by intraperitoneal administration of $1 \mathrm{X} 108$ $\mathrm{SRBC}$ in $25 \mu \mathrm{L}$ normal saline. Birds were exposed to FO smoke for 1 hour per day for 4 consecutive days. SRBC was administered after the second exposure. The antibody response of these birds was compared to those of non-immunized control and FO exposed birds. After 7 days of challenge, blood was collected by heart puncture and the birds euthanized with $\mathrm{CO}_{2}$. Serum was collected from whole blood as described by Fairbrother and Fowles (1990) and stored at $-70^{\circ} \mathrm{C}$ until assayed for antibody titer. Following heat inactivation $\left(56^{\circ} \mathrm{C}\right.$ for 30 minutes $)$, the samples were serially diluted twofold in 96-well U-bottom microtiter plates (Gibco, Grand Island, NY). To determine the relative proportion of IgM (2-mercaptoethanol sensitive) antibodies to the total antibody titer, each sample was diluted in duplicate, one in saline and the second in saline to which was added $50 \mu \mathrm{L}$ of $0.2 \mathrm{M} 2$-mercaptoethanol (2-ME). Samples were then incubated at $37^{\circ} \mathrm{C}$ for 30 minutes, at which time $50 \mu \mathrm{L}$ of a $0.5 \%$ suspension of SRBC was added to all wells (Figure 1). The microtiter plates were left at room temperature overnight and read the following day. The 2ME sensitive antibodies levels were determined by subtracting the 2-ME resistant (IgG) antibody titer from the total antibody titer. The antibody titers were expressed as the inverse of the highest dilution of serum showing hemagglutination of SRBC. Peak response time ( 7 to 8 days) was determined from a preliminary test in which house sparrows were immunized with SRBC and sacrificed on days 4, 6, 7, 8, and 10 post-injection.

To assess the functional integrity/capacity of the major organs, several metabolic end points were measured including calcium, cholesterol, glucose, total protein, albumin, globulin, and uric acid. Blood was collected from each bird at necropsy by heart stick and the sample transferred to a microtainer serum separator tube and centrifuged at 14,000 rpm for $10 \mathrm{~min}$. The clot was removed and the serum stored 
at $-70^{\circ} \mathrm{C}$ until analysis. Metabolite concentrations were determined using a Hitachi model 7170 clinical analyzer. Cholesterol, glucose, and uric acid were analyzed enzymatically using microbial cholesterol esterase, hexokinase, and uricase, respectively. Dye binding techniques were used for the calcium and albumin determinations and total protein was determined by biuret method.

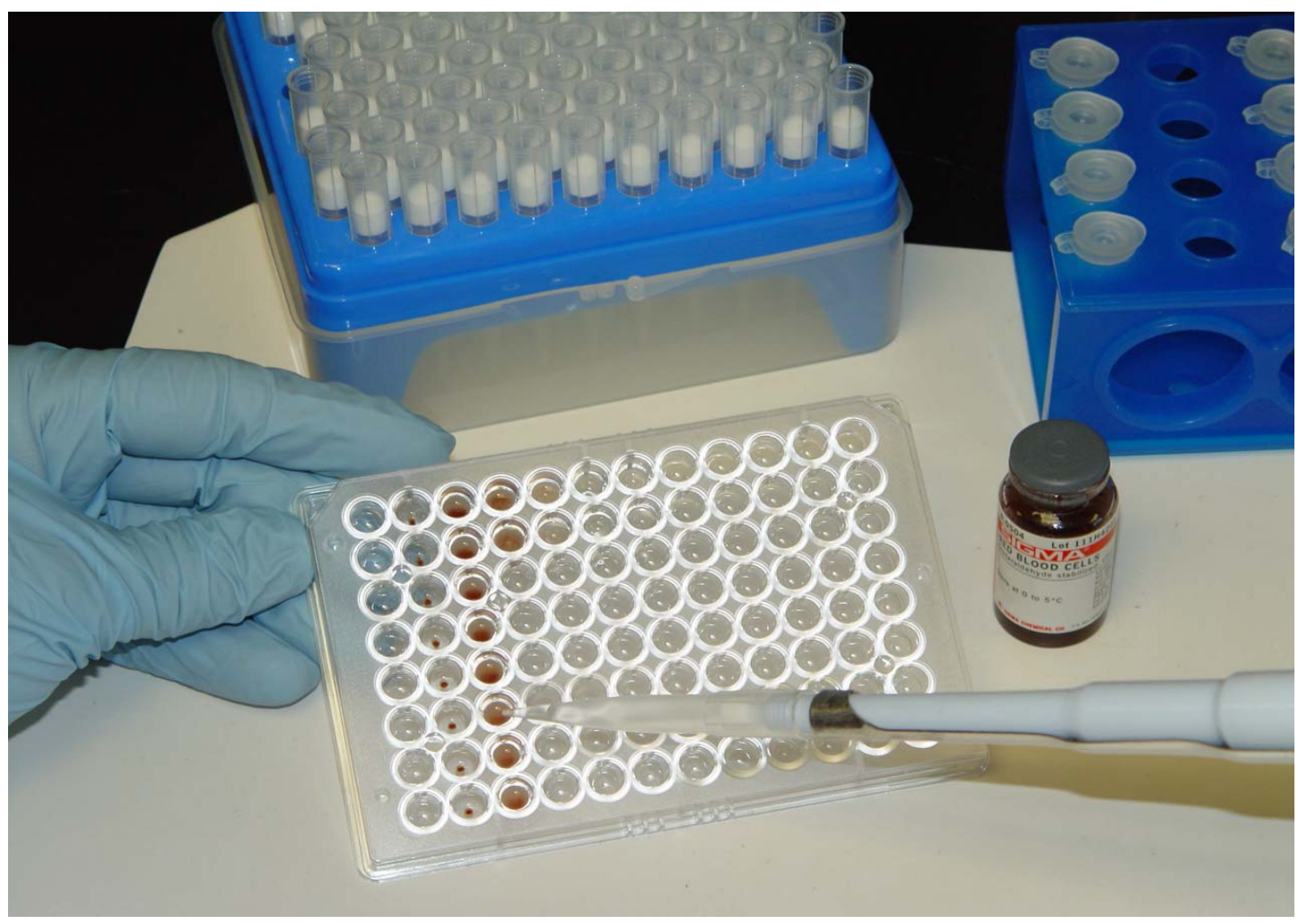

Figure 1. Evaluating the effect of fog oil on humoral immunity in house sparrows.

\section{Mortality and Clinical Signs of Toxicity and/or Stress}

Visual observations for clinical signs of toxicity, mortality, and moribund birds were recorded twice daily (before 10:00 hours and after 15:00 hours).

\section{Body Weight and Organ Mass}

Body weights were measured to the nearest gram on a Sartorius QS4000 Balance at the beginning and termination of the test and at intervals during the post-exposure observation period. Organ weights were obtained at necropsy. The tissue mass was determined to the nearest milligram using a Mettler AE260 Analytical Balance. 


\section{Gross Lesions and Histopathology}

A gross necropsy was performed on each bird. Birds were sacrificed by carbon dioxide asphyxiation. Immediately following sacrifice, the intestines were excised, examined and injected with $10 \%$ buffered formalin to prevent autolysis. All major organs were examined for gross lesions. The breast muscle was examined for atrophy and the terminal body weight, general body condition, and presence of body fat recorded. The amount $(\mathrm{mm})$ of the sternum (keel) protruding from the breast muscle was measured with calipers, and body fat deposition in the abdominal area was ranked from 1 (minimal fat) to 5 (protruding fat). Air sacs were viewed for lesions and clarity of tissue. The skin, lung, trachea, heart, liver, spleen, proventriculus, pancreas, small and large intestine, gizzard, kidney, and gonad were excised and preserved in $10 \%$ buffered formalin. The trachea and lung were perfused with formalin prior to storage in sample jars containing buffered formalin. Tissues were prepared for histologic examination and submitted for reading by a veterinary pathologist. Tissues were labeled so that the specific experimental treatment of individual birds was not identifiable by the pathologist.

\section{Hematology and Blood Chemistry}

As measures of stress and the impact of fog oil on immune response, leucocyte numbers and morphology in peripheral blood were examined. Because hemolytic, regenerative anemia is well documented in birds exposed to petroleum products (Leighton 1986), erythrocyte morphology and packed cell volume (PCV) were measured in the red-winged blackbirds to determine the incidence of anemia among treated birds and the ability of the bone marrow to respond to the anemic state.

Cytologic examination of the peripheral blood of both sparrows and blackbirds was performed at necropsy. Blood smears were obtained immediately following blood collection to preserve cell morphology and were made using a standard 2-slide wedge technique. Differential white cell counts were performed on blood smears stained with a Wright-Giemsa stain. Total white cell counts were performed using Natt-Herrick's stain with a hemocytometer. Cells were stained and classified according to Dein (1984). Leukocyte, thrombocyte, and erythrocyte morphology were evaluated for signs of toxicity (degeneration) and the degree of toxicity reported subjectively on a scale of +1 to +4 ; a value of +1 reflected a slight damage and +4 indicated severe damage. Abnormal leukocyte morphology was described by increased cytoplasmic basophilia, vacuolation, immature or abnormal cytoplasmic granules, degranulation, and nuclear karyolyis. Toxic changes in thrombocytes were noted by diffuse eosinophilic cytoplasm, spindle shaped cells and immature cells. Erythrocyte toxicity was characterized by presence of immature erythrocytes, polychroma- 
sia, variations in nucleus location and shape, cytoplasmic basophilic stippling, and agglutination.

Hematocrit was determined on whole blood samples from the red-winged blackbirds only. The packed cell volume (PCV) was obtained by centrifugation of a blood-filled microhematocrit tube at $12,000 \mathrm{~g}$ (standard acceleration of gravity) for 5 minutes.

Several clinical chemistries were also conducted on the peripheral blood of the redwinged blackbirds. End-point metabolites including calcium, cholesterol, glucose, total protein, albumin, globulin, and uric acid were measured to assess the functional integrity/capacity of the major organs. Blood was collected from each bird at necropsy by heart stick and the sample transferred to a MICROTAINER® brand serum separator tube and centrifuged at 14,000 rpm for 10 minutes. The clot was removed and the serum stored at $-70^{\circ} \mathrm{C}$ until analysis. Metabolite concentrations were determined using a Hitachi ${ }^{\circledR}$ model 7170 clinical analyzer and the reagents and procedures standardized for use with the analyzer. Cholesterol, glucose, and uric acid were analyzed enzymatically using microbial cholesterol esterase, hexokinase, and uricase, respectively. Dye-binding techniques were used for the calcium and albumin determinations and total protein was determined by biuret method.

Cell counts and metabolite concentrations of treated birds were compared to control values and to published reference intervals that define the normal limits for healthy populations of passerine species (Altman et al. 1997).

\section{Data Analysis}

For multiple comparisons, determination of significant differences concerning the same parameter was measured using one-way analysis of variance (ANOVA) at an alpha level of 0.05 and the means separated by Dunnet's t-test. The Student t-test was used to compare variances of two samples. Those blood parameters expressed in a ratio were analyzed using an arcsine transformation. The software system SAS® (SAS Institute, 1995, Cary, North Carolina) was used to conduct all statistical analyses. 


\section{Results and Discussion}

\section{Immune Status}

Avianpox lesions were observed in $100 \%$ of the control blackbirds and in $80 \%$ of the blackbirds exposed to FO smoke (Table 1) and were confirmed by presence of Bollinger bodies. The cutaneous form ("dry pox") was observed in both the controls and FO treated groups, but the diphtheroid form ("wet pox") was found only among the controls. Forty three percent of the control birds had severe diphtheroid lesions in the pharynx. Bloody exudate was observed at the oral foci in one of these birds. Only one bird from the FO-exposed group displayed severe cutaneous lesions that involved the eye. The rest of the cases were mild to moderate in severity and the lesions largely confined to the unfeathered area around the beak. The lesions in all but 2 birds in the FO-exposed group had progressed to the encrusted or desquamation stage by the time of necropsy. Recovery was also evident in those control birds exhibiting only the dry pox lesions.

Table 1. Body condition and incidence of histopathologic lesions in red-winged blackbirds exposed to fog oil smoke.

\begin{tabular}{|c|c|c|c|c|c|}
\hline \multirow[b]{2}{*}{ Treatment } & \multicolumn{2}{|c|}{ Fat Index } & \multicolumn{2}{|c|}{ Avianpox Lesions } & \multirow[b]{2}{*}{ Parasites } \\
\hline & Stores & Keel & Cutaneous & Diptheroid & \\
\hline Control & $\begin{array}{l}2.0^{b} \\
(0.46)\end{array}$ & $\begin{array}{l}3.3^{C} \\
(0.32)\end{array}$ & $6 / 8^{d}$ & $3 / 8$ & $6 / 8^{e, f}$ \\
\hline Fog Oil & $\begin{array}{l}2.7 \\
(0.56) \\
\end{array}$ & $\begin{array}{l}3.9 \\
(0.25) \\
\end{array}$ & $14 / 17$ & 0/17 & $8 / 17^{\mathrm{e}}$ \\
\hline \multicolumn{6}{|c|}{$\begin{array}{l}\text { (a) Fog oil concentration was } 300 \mathrm{mg} / \mathrm{m}^{3} \text { for } 1 \text { hour per day for } 4 \text { consecutive days. } \\
\text { (b) Values are mean values from a scale of } 1 \text { to } 5 \text { of the amount of fat in the abdominal region. } \\
\text { (c) Values are amount of sternum (keel) in } \mathrm{mm} \text { protruding from breast muscle. } \\
\text { (d) Values are the number of birds with lesions/number of birds in test group. } \\
\text { (e) Coccidia } \\
\text { (f) One helminth }\end{array}$} \\
\hline
\end{tabular}

The number of WBCs in the peripheral blood of red-winged blackbirds exposed to FO smoke was somewhat higher than those in the peripheral blood of control blackbirds, but the differences were not statistically significant (Table 2). WBC counts were within normal ranges reported for passerines (3000 to 9000 cells $/ \mu \mathrm{L}$; Altman et al. 1997). No toxic changes were observed in the leukocytes of the blackbirds. 
Table 2. Total and differential white blood cell counts for adult female red-winged blackbirds exposed to fog oil smoke.

\begin{tabular}{|l|l|l|}
\hline Cell Type $^{\mathrm{b}}$ & Control & Fog Oil \\
\hline Heterophile & $61.3(7.9)$ & $60.0(7.5)$ \\
\hline Lymphocyte & $36.4(7.5)$ & $38.0(7.3)$ \\
\hline Monocyte & $2.4(0.7)$ & $2.5(0.6)$ \\
\hline Eosinophile & 0 & 0 \\
\hline Basophile & 0 & 0 \\
\hline TOTAL WBC & $3000(327)$ & $3471(289)$ \\
\hline PCV & $60.3(5.4)$ & $65.0(2.0)$ \\
\hline
\end{tabular}

Values are means with standard error in parentheses.

(a) Fog oil concentration was $300 \mathrm{mg} / \mathrm{m}^{3}$ for 1 hour per day for 4 consecutive days.

(b) Expressed as percentage of total number of WBCs. T-test performed on arcsine-transformed percentages.

(c) Expressed as cells/ $\mu \mathrm{L}$.

In addition to the lack of leukocyte depression in FO-exposed blackbirds, hemolytic anemia was not observed in any of the treated blackbirds. Only one red-winged blackbird had an abnormal erythron. This bird displayed mild $(+1)$ anisocytosis (size variation between red blood cells) and mild polychromasia (color variation between red blood cells). Although increases in erythrocyte polychromasia and anisocytosis are seen in clinical anemia, slight to mild polychromasia, such as observed in this bird, is common and is indicative of normal red blood cell regeneration (Richie, Harrison, and Harrison 1994). In addition, hematocrit levels for treated red-winged blackbirds were not different from those of controls (Table 2) and were within reference ranges reported for healthy passerines (Altman et al. 1997). Adequate thrombocyte counts were found in all blackbirds and no toxic changes were observed in these cells.

Oral doses of petrochemicals in direct pathogen challenge tests reduced the ability of leukocytes to phagocytize and kill Pasteurella multocida, the agent of avian cholera (Rocke, Yuill, and Hinsdill 1984). In contrast, no immunosuppresion was observed in this study. The lack of response may be because field concentrations and the different routes of exposure in smoke scenarios do not deliver sufficient dose to target systems, because FO itself is less damaging to the immune system, or because the response to the pathogens or their relative virulence is different.

\section{Hemagglutination}

Exposure to FO smoke for 4 days did not affect the total, 2-ME sensitive (IgM), or 2$\mathrm{ME}$ resistant (IgG) antibody titers in sparrows when compared to titers from control serum (Table 3). The lack of impact on humoral response is consistent with studies 
investigating the effect of ingested petrochemicals in waterfowl and domestic birds (Arstila, Vainio, and Lassila 1994; Goldberg, Yuill, and Burgess 1990). Cellular response to the SRBC challenge and FO exposure was not significant (Table 4). Monocyte numbers were significantly increased in FO exposed birds over those found in immunized controls. Although there was a relative increase in monocytes, a hallmark of chronic infection, the actual number of cells observed was very low and more typical of normal counts (Altman et al. 1997).

Table 3. Total, 2-Mercaptoethanol-sensitive (IgM), and 2-Mercaptoethanol-resistant (IgG) antibody titers in house sparrows at 7 days after primary immunization with sheep red blood cells.

\begin{tabular}{|l|c|l|c|c|}
\hline \multirow{2}{*}{ Treatment } & $\mathbf{n}$ & \multicolumn{3}{|c|}{ Temagglutinating Antibody Titer } \\
\cline { 3 - 5 } & 14 & $2.5 \pm 0.9$ & $1.0 \pm 0.7$ & $1.6 \pm 0.4$ \\
\hline Control & 14 & $2.6 \pm 1.0$ & $1.3 \pm 0.6$ & $1.5 \pm 0.4$ \\
\hline Fog Oil & 14 IgG \\
\hline \multicolumn{4}{l}{ Values are expressed in $\log _{2}$} \\
\hline
\end{tabular}

Table 4. Total and differential white blood cell counts for house sparrows exposed to fog oil smoke. ${ }^{a}$

\begin{tabular}{|c|c|c|c|c|}
\hline \multirow[b]{2}{*}{ Cell Type ${ }^{b}$} & \multicolumn{2}{|l|}{ Control } & \multicolumn{2}{|l|}{ Fog Oil } \\
\hline & Non-immunized & Immunized & Non-immunized & Immunized \\
\hline Heterophile & $50(8.5)$ & $60(5.9)$ & $55(9.7)$ & $61(9.4)$ \\
\hline Lymphocyte & $50(8.3)$ & $40(6.0)$ & $41(10.1)$ & $38(9.5)$ \\
\hline Monocyte & $0.8(0.4)^{\mathrm{d}, \mathrm{e}}$ & $0.3(0.1)^{d}$ & $1.6(0.5)^{\mathrm{e}, \mathrm{f}}$ & $1.9(0.4)^{f}$ \\
\hline Eosinophile & 0 & 0 & 0 & 0 \\
\hline Basophile & 0 & 0 & 0 & 0 \\
\hline TOTAL WBC $^{\mathrm{C}}$ & 1231 (109) & $1352(168)$ & $2300(646)$ & $1583(208)$ \\
\hline \multicolumn{5}{|c|}{$\begin{array}{l}\text { Values are means with standard error in parentheses. } \\
\text { (a) Fog oil concentration was } 435 \mathrm{mg} / \mathrm{m}^{3} \text { for } 1 \text { hour per day for } 4 \text { consecutive days. } \\
\text { (b) Expressed as percentage of total number of WBCs. }\end{array}$} \\
\hline
\end{tabular}

Two deaths occurred during the study. A control bird was found dead on the third day of treatment and a FO-exposed bird died on day four of exposure. Histological lesions were unremarkable for these birds and death appeared to be unrelated to treatment. 


\section{Pathology and Toxic Response}

Blood chemistries of the blackbirds are shown in Table 5. FO exposure did not appear to alter metabolite concentrations in the peripheral blood and all metabolites were within reference ranges that characterize normal organ function in birds (Altman et al. 1997). Although not statistically different, glucose concentrations in FO-exposed blackbirds were higher (30\%) than those of the controls. Blood glucose levels in controls were more variable and quite depressed $(69 \mathrm{mg} / \mathrm{dl}$ to $99 \mathrm{mg} / \mathrm{dl})$ in two of the birds displaying wet pox and one bird with dry pox. It may be that the lesions were inhibiting their ability to obtain or swallow food. If the lesions were disrupting food consumption, the disruption was probably recent as the body weight and fat index of the controls were somewhat lower but not yet affected significantly (Table 1). Body fat was not affected by treatment in house sparrows inoculated with SRBCs (Table 6).

Table 5. Blood chemistry of female red-winged blackbirds exposed to fog oil smoke.

\begin{tabular}{|c|c|c|}
\hline Metabolite $^{b}$ & Control & Fog Oil \\
\hline Protein & $5.6(0.34)$ & $5.1(0.43)$ \\
\hline Albumin & $2.6(0.24)$ & $2.4(0.22)$ \\
\hline Globulin & $3.0(0.25)$ & $2.5(0.18)$ \\
\hline$A / G$ & $0.91(0.06)$ & $0.95(0.05)$ \\
\hline Cholesterol & $413(16)$ & $397(40)$ \\
\hline Uric Acid & $8.1(2.3)$ & $8.6(1.2)$ \\
\hline Glucose & $236(48)$ & 337 (34) \\
\hline Calcium & $11.0(1.02)$ & $11.6(0.60)$ \\
\hline \multicolumn{3}{|c|}{$\begin{array}{l}\text { Values are means with standard error in parentheses; } n=8 \text { for control, } n=17 \text { for fog } \\
\text { oil treated birds. } \\
\text { (a) Fog oil concentration was } 300 \mathrm{mg} / \mathrm{m}^{3} \text { for } 1 \text { hour per day for } 4 \text { consecutive days. } \\
\text { (b) Values for protein are in } \mathrm{g} / \mathrm{dL} \text {; all other metabolites are reported in } \mathrm{mg} / \mathrm{dL} \text {. No } \\
\text { statistically significant differences were found between any metabolite of the } \\
\text { control and fog oil treated birds. }\end{array}$} \\
\hline
\end{tabular}

Mean body weights of the house sparrows and red-winged blackbirds during the test period are presented in Table 6 and Figure 2, respectively. No differences in body weight between control and treated birds were observed throughout the study period in either species. Reports on the effects of oral ingestion of petrochemicals on body mass and growth in birds are conflicting and may be a result of the use of different crude oils and refined products, different dosing regimes, and the varying ages of the birds (Clark 1984). Apparently the combined doses acquired from wholebody exposure to FO smoke in this study were below concentrations that cause weight loss. 
Table 6. Body condition, body weights and organ mass of house sparrows exposed to fog oil smoke.

\begin{tabular}{|c|c|c|c|c|c|c|c|}
\hline \multirow[b]{2}{*}{ Treatment } & \multicolumn{2}{|c|}{ Fat Index } & \multirow{2}{*}{$\begin{array}{l}\text { Body } \\
\text { Weight }\end{array}$} & \multicolumn{4}{|c|}{ Organ Mass (\% Body Weight) } \\
\hline & Store & Keel & & Liver & Spleen & Pancreas & Kidney \\
\hline \multicolumn{8}{|l|}{ Control } \\
\hline Non-immunized & $\begin{array}{l}2.3^{b} \\
(0.3)\end{array}$ & $\begin{array}{l}4.8^{c} \\
(0.4)\end{array}$ & $\begin{array}{l}24.9 \\
(0.5)\end{array}$ & $\begin{array}{l}3.675 \\
(0.158)\end{array}$ & $\begin{array}{l}0.097 \\
(0.025)\end{array}$ & $\begin{array}{l}0.423 \\
(0.034)\end{array}$ & $\begin{array}{l}0.958 \\
(0.059)\end{array}$ \\
\hline Immunized & $\begin{array}{l}2.2 \\
(0.4)\end{array}$ & $\begin{array}{l}3.8 \\
(0.5)\end{array}$ & $\begin{array}{l}24.9 \\
(0.3)\end{array}$ & $\begin{array}{l}3.706 \\
(0.136)\end{array}$ & $\begin{array}{l}0.183 \\
(0.037)\end{array}$ & $\begin{array}{l}0.519 \\
(0.021)\end{array}$ & $\begin{array}{l}0.946 \\
(0.046)\end{array}$ \\
\hline \multicolumn{8}{|l|}{ Fog Oil Aerosol } \\
\hline Non-immunized & $\begin{array}{l}1.5 \\
(0.3)\end{array}$ & $\begin{array}{l}4.1 \\
(0.3)\end{array}$ & $\begin{array}{l}24.0 \\
(0.6)\end{array}$ & $\begin{array}{l}3.746 \\
(0.213)\end{array}$ & $\begin{array}{l}0.147 \\
(0.026)\end{array}$ & $\begin{array}{l}0.499 \\
(0.041)\end{array}$ & $\begin{array}{l}1.00 \\
(0.043)\end{array}$ \\
\hline Immunized & $\begin{array}{l}2.3 \\
(0.2)\end{array}$ & $\begin{array}{l}3.8 \\
(0.3)\end{array}$ & $\begin{array}{l}24.8 \\
(0.5)\end{array}$ & $\begin{array}{l}3.724 \\
(0.141)\end{array}$ & $\begin{array}{l}0.175 \\
(0.040)\end{array}$ & $\begin{array}{l}0.552 \\
(0.025)\end{array}$ & $\begin{array}{l}0.949 \\
(0.051)\end{array}$ \\
\hline \multicolumn{8}{|c|}{$\begin{array}{l}\text { Values in parentheses are the standard error of the mean. } \\
\text { (a) Fog oil concentration was } 435 \mathrm{mg} / \mathrm{m}^{3} \text { for } 1 \text { hour per day for } 4 \text { consecutive days. } \\
\text { (b) Values are mean values from a scale of } 1 \text { to } 5 \text { of the amount of fat in the abdominal region. } \\
\text { (c) Values are amount of sternum (keel) in mm protruding from breast muscle. } \\
\text { ANOVA was applied to the arcsine transformation values of the tissue weight proportions. }\end{array}$} \\
\hline
\end{tabular}

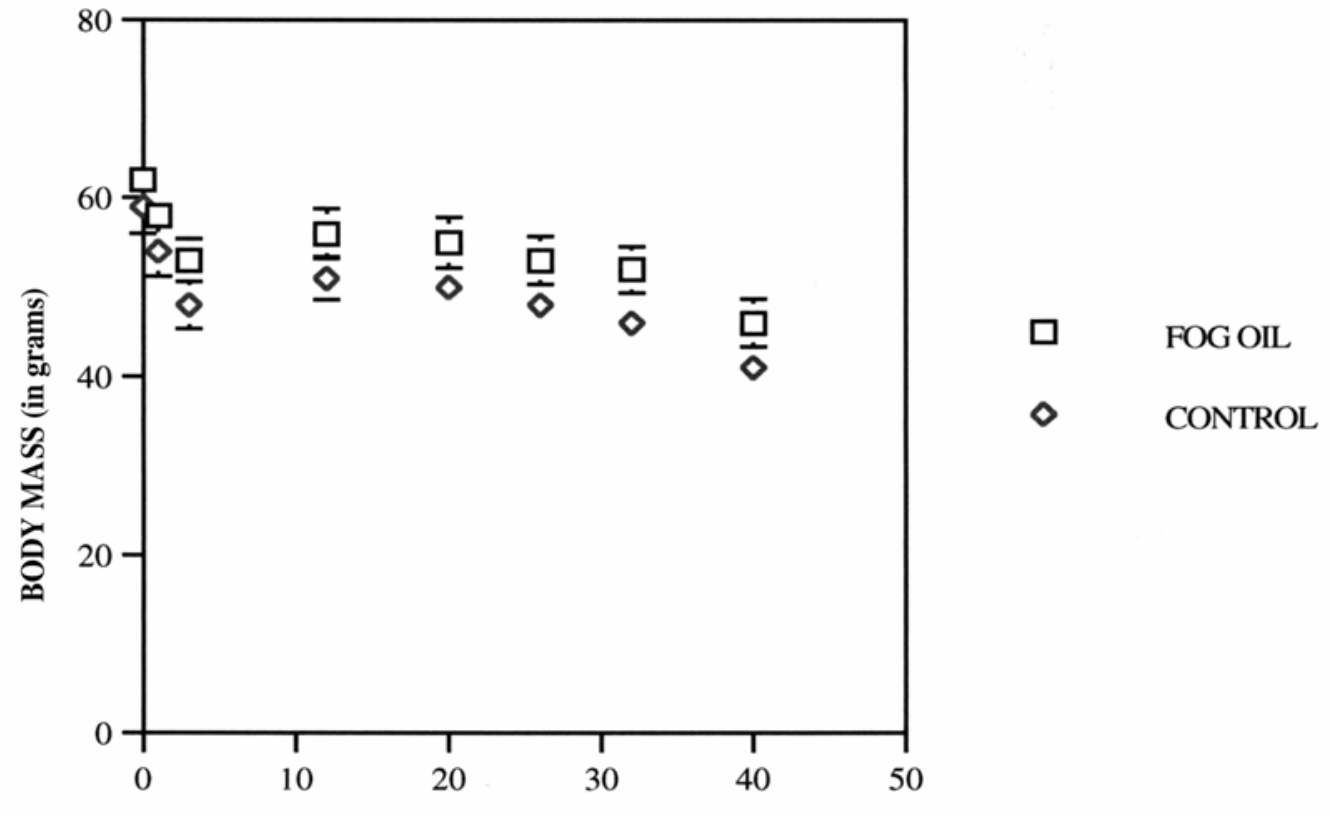

DAY POST EXPOSURE

Figure 2. Body mass (in grams) of female red-winged blackbirds exposed to fog oil smoke and avianpox. 
Organ weights (normalized by body weight) of treated blackbirds and house sparrows were similar to those reported for healthy birds on a per body weight basis (Miller et al. 1978; Miller, Peakall, and Kinter 1978). However, the mean liver mass of the FO-exposed blackbirds was significantly smaller than that of control birds (Table 7). This is in contrast to the hypertrophy of hepatic tissue observed in birds given a single oral dose of petroleum (Miller et al. 1978; Miller, Peakall, and Kinter 1978; Peakall et al. 1982). The cause of the hypertrophy is not known. Spleens of non-immunized house sparrows appeared to be smaller (although not statistically significant) than those of immunized birds as would be expected in response to the antigen. However, the larger mean mass of spleens from the non-immunized FOexposed sparrows is in contrast to observed depression of lymphoid tissue in birds ingesting petrochemicals (Holmes, Gorsline, and Cronshaw 1979). Three birds (2 exposed to FO and 1 control) had a massive proliferation of uniform small lymphocytes within the lamina propria of the intestine that effaced all other structures. The lesion appears to be related to internal parasitism and again contrasts lymphocyte suppression observed in seabirds that have ingested crude oil or petroleum distillates.

Table 7. Organ weights (as percentage of body weight) of red-winged blackbirds exposed to fog oil smoke.

\begin{tabular}{|c|c|c|}
\hline \multirow[b]{2}{*}{ Organ } & \multicolumn{2}{|c|}{ Treatment } \\
\hline & Control & Fog Oil \\
\hline Liver & $\begin{array}{l}3.7^{b} \\
(0.74)^{d}\end{array}$ & $\begin{array}{l}2.9^{C} \\
(0.16)\end{array}$ \\
\hline Spleen & $\begin{array}{l}0.12 \\
(0.044)\end{array}$ & $\begin{array}{l}0.13 \\
(0.037)\end{array}$ \\
\hline Pancreas & $\begin{array}{l}0.31 \\
(0.021) \\
\end{array}$ & $\begin{array}{l}0.26 \\
(0.027) \\
\end{array}$ \\
\hline Kidney & $\begin{array}{l}0.90 \\
(0.079)\end{array}$ & $\begin{array}{l}0.76 \\
(0.102)\end{array}$ \\
\hline \multicolumn{3}{|c|}{$\begin{array}{l}\text { (a) Fog oil concentration was } 300 \mathrm{mg} / \mathrm{m}^{3} \text { for } 1 \text { hour per day for } \\
4 \text { consecutive days. } \\
\text { (b,c) T-test was applied to the arcsine transformation values of } \\
\text { the tissue weight proportions; means with different } \\
\text { superscripts are significantly different. ANOVA, } P<=0.05 \text {. } \\
\text { (d) Values in parentheses are the standard error of the mean; } \\
n=8 \text { for control group, } n=17 \text { for fog oil exposed group. }\end{array}$} \\
\hline
\end{tabular}


Mild infections of coccidia were observed histologically in most of the blackbirds and house sparrows (Tables 1 and 8). No evidence of intestinal damage was observed histologically in infected birds and the infections did not confound the histopathologic response in this tissue. Coccidial infection was observed in both control and treated birds and followed a subclinical course independent of the treatments.

Table 8. Histopathologic lesions in house sparrows exposed to fog oil smoke.

\begin{tabular}{|l|l|l|l|l|l|}
\hline Treatment & Severity & Hepatitis & Enteritis & Coccidiosis & Fatty Change \\
\hline Control & Mild & 5 & 0 & 3 & 1 \\
& Mod & 3 & 0 & 2 & 0 \\
& Sev & 1 & 1 & 2 & 0 \\
\hline Control & Mild & 10 & 0 & 3 & 0 \\
Immunized & Mod & 3 & 0 & 4 & 0 \\
& Sev & 1 & 0 & 2 & 0 \\
\hline Fog Oil & Mild & 4 & 0 & 3 & 0 \\
& Mod & 6 & 1 & 1 & 0 \\
& Sev & 2 & 5 & 0 & 0 \\
\hline Fog Oil & Mild & 7 & 0 & 5 & 3 \\
Immunized & Mod & 2 & 2 & 2 & 0 \\
& Sev & 1 & 0 & 3 & 0 \\
\hline (a) Fog oil concentration was $435 \mathrm{mg} / \mathrm{m}^{3}$ for 1 hour per day for 4 consecutive days. \\
$\mathrm{n}=11$ for non-immunized groups; $\mathrm{n}=14$ for immunized groups. \\
\hline
\end{tabular}

Lesions in the sparrow consisted of foci of inflammation in the liver likely related to prior infection or antigenic stimulus as these lesions were also found in nonimmunized birds (Table 8). Four birds had mild fatty liver change in the liver, a reversible injury that is not specific for any particular etiology. Metabolic disturbances as well as toxicities can cause this lesion (Lumeij 1994). However, mild degenerative changes in the liver, including fatty change, have been observed in a number of wild or experimentally oiled birds (Hartung and Hunt 1966; Beer 1968; Snyder, Fox and Soare 1973; Szaro, Hensler, and Heinz 1981; Pattee and Franson 1982) and three of the four cases of fatty liver in this study were from a FO-exposed group. The other case, however, was a control bird indicating that the cellular injury was probably from causes unrelated to FO exposure. 


\section{Conclusions}

In vivo responses to direct challenge with a pathogen did not suppress cell-mediated immunity in red-winged blackbirds exposed to $\mathrm{FO}$ for 4 consecutive days. Infection and severity of avianpox lesions were somewhat greater in control birds than in birds exposed to FO. Total and differential WBC counts indicated that non-specific immune function was not diminished by the treatments. Changes in spleen mass and structure were not observed, providing additional evidence that airborne fog oil aerosols at higher than field-typical concentrations do not induce immune dysfunction. Further, the incidence of parasitism, which plays a role in population regulation, was found to be unrelated to treatment.

Total antibody response to SRBC by house sparrows was not changed by FO exposure. Titers of 2-ME-sensitive or 2-ME resistant antibody of FO treated sparrows did not differ from antibody titers of the controls, indicating that FO does not affect antibody-mediated immunity.

In addition, no mortality, clinical signs of toxicity, or poor response to weather fluctuations appeared to be induced by exposure to FO. Although mild fatty change of the liver and enteritis were observed in FO-exposed sparrows, the presence of similar lesions in control birds suggests that they are not the result of petrochemical exposure. No damage to major organs and tissues from exposure to FO was seen. End point metabolite levels in peripheral blood indicated that the functional integrity/capacity of the major organs was intact. Hematologic response was normal and no blood cell damage was observed. Thus, it appears that exposure to high field concentrations of FO obscurant smoke for 1 hour per day for 4 consecutive days does not result in mortality, long-term organ dysfunction, sublethal gross lesions, significant histopathology, or immunomodulation in adult house sparrows or red-winged blackbirds.

In view of the lack of significant effect of high, near-source field concentrations of FO on immune responses in either of the surrogate species, the training use of fog oil as an obscurant does not appear to pose a threat to the immune system health of adult birds, including listed species such as the red-cockaded woodpecker. 


\section{References}

Altman, R. B., S. L. Clubb, G. M. Dorrestien, K. Quessenberry. 1997. Avian Medicine and Surgery. W. B. Saunders Co., Philadelphia, PA, pp. 1004-1022.

Arstila, T. P., O. Vainio, and O. Lassila. 1994. "Central role of CD4+T cells in avian immune responses.” Poultry Sci. 73:1019-1026.

Beer, J. V. 1968. "Postmortem findings in oiled auks dying during attempted rehabilitation." In The Biological Effects of Oil Pollution on Littoral Communities, J. D. Carthy and D. R. Arthur (eds), pp. 123-129. Field Studies Council, London.

Briggs, K. T., S. H. Yoshida, and M. E. Gershwin. 1996. "The influence of petrochemicals and stress on the immune system of seabirds." Reg. Toxicol Pharmacol. 23:145-155.

Briggs, K. T., M. E. Gershwin, and D. W. Anderson. 1997. "Consequences of petrochemical ingestion and stress on the immune system of seabirds.” J. Marine Sci. 54:718-725.

Burger, A. E., and D. M. Fry. 1993. "Effects of oil pollution on seabirds in the northeast Pacific." In The status, ecology and conservation of marine and shoreline birds of the North Pacific, K. Vermeer, K. T. Briggs, K. H. Morgan, and D. Seigel-Causey (eds), pp. 254-263. Special Publication of the Canadian Wildlife Service, Ottawa.

Clark, R. B. 1984. "Impact of Oil Pollution on Seabirds." Environ. Pollution (Series A) 33:1-22.

Croxall, J. P. 1977. "The effects of oil on seabirds." International Council for the Exploration of the Sea, 171:191-195.

Dein, F. J. 1984. Laboratory Manual of Avian Hematology. Association of Avian Veterinarians, East Northport, New York.

Driver, C., L. Smith, J. Briant, P. Van Voris, A. Fairbrother, and P. Buchholz. 1990. Laboratory Test Methods of Exposure of Microbial Pest Control Agents by the Respiratory Route to Nontarget Avian Species. EPA/600/3-90/070. I. S. Environmental Protection Agency, Environmental Research Laboratory, Corvallis, Oregon.

Driver, C. J., M. W. Ligotke, J. L. Downs, B. L. Tiller, T. M. Poston, E. B. Moore, Jr., and D. A. Cataldo. 1993. Environmental and Health Effects Review for Obscurant Fog Oil. Report Number ERDEC-CR-071, U.S. Army Chemical and Biological Defense Agency, Edgewood Research, Development and Engineering Center, Aberdeen Proving Ground, Maryland. 
Driver, C. J., M. W. Ligotke, H. Galloway-Gorby, G. Dennis, K. A. Reinbold and H. E. Balbach. 2002a. Acute Inhalation Toxicity of Fog Oil Smoke in the Red-winged Blackbird, a Sizespecific Inhalation Surrogate for the Red-cockaded Woodpecker. ERDC/CERL Technical Report, TR-02-6, ADA399210. Engineer Research and Development Center, Construction Engineering Research Laboratory, Champaign, IL.

Driver, C. J., J. Ollero, Y. F. Su, R. Fulton, G. Dennis, B. Tiller, H. E. Balbach, and K. A. Reinbold. 2002b. Effects of Fog Oil Smoke on the Hatchability and Fledgling Survival of the House Sparrow (Passer domesticus), a Nestling Surrogate for the Red-cockaded Woodpecker., ERDC/CERL Technical Report TR-02-34, ADA411029. Engineer Research and Development Center, Construction Engineering Research Laboratory, Champaign, IL.

Eberhard, W. L., R. E. Cupp, and N. L. Abshire. 1989. "Conservation Properties of Oil Fog Used as an Atmospheric Tracer.” Atmos. Environ. 23(8):1855-1861.

Fairbrother, A., and J. Fowles. 1990. "Subchronic effects of sodium selenite and selenomethionine on several immune-functions in mallards." Arch. Environ. Contam. Toxicol. 19:836-844.

Goldberg, D. R., T. M. Yuill, and E. C. Burgess. 1990. "Mortality from duck plague virus in immunosuppressed adult mallard ducks." J. Wildl Disease. 26:299-306.

Hartung, R., and G. S. Hunt 1966. “Toxicity of some oils to waterfowl.” J.Wildl. Manage. 31:564570.

Holmes, W. N., J. Gorsline, and J. Cronshaw. 1979. "Effects of mild cold stress on the survival of seawater adapted mallard ducks (Anas platyrhynchos) maintained on food contaminated with petroleum.” Environ. Res. 20:424-444.

Kerkvliet, N. I., L. Baecher-Steppan, A. T. Claycomb, A. M. Craig, and C. G. Sheggeby. 1982. "Immunotoxicity of technical pentachlorophenol (PCP-T): Depressed humoral immune responses to T-dependent and T-independent antigen stimulation in PCP-T exposed mice." Fundam. Appl. Toxicol. 2:90-99.

Leighton, F. A. 1986. "Clinical, gross and histological findings in herring gulls and Atlantic puffins that ingest Prudhoe Bay crude oil.” Veterinary Pathol. 23:254-263.

Lumeij, J. T. 1994. "Nephrology." In Avian Medicine, Principles and Application. B. Ritchie, G. Harrison, and L. Harrison (eds.), Wingers Publishing, Inc, Lake Worth, Florida.

McOrist, S., and C. Lenghaus. 1992. "Mortalities of little penguins (Eudyptula minor) following exposure to crude oil." Veterinary Rec. 130:161-162.

Miller, D. A., J. Kahn, E. Shaeen, D. B. Peakall, W. B. Kinter. 1978. "Effects of ingestion of a weathered crude oil on immature black guillemots, Cepphus grylle, and herring gulls, Larus argentatus." Bull. Mt. Desert Is. Biol. Lab. 17:40-42.

Miller, D. S., D. B. Peakall, and W. B. Kinter. 1978. "Ingestion of crude oil: sublethal effects in herring gull chicks." Science 199:315-317.

Pattee, O. H., and J. C. Franson. 1982. "Short-term effects of oil ingestion on American kestrels (Falco sparverius)." J. Wildl. Dis. 18:235-241. 
Peakall, D. B., D. J. Hallett, J. R. Bend, G. L. Fourman, and D. S. Miller. 1982. "Toxicity of Prudhoe Bay crude oil and its aromatic fractions to nestling herring gulls." Environ. Res. 27:206-215.

Richie, B. W., G. J. Harrison, and L. R. Harrison. 1994. Avian Medicine: Principles and Application. Wingers Publishing, Inc., Lake Worth, Florida, pp. 865-874.

Rocke, T. E., T. M. Yuill, and R. D. Hinsdill. 1984. "Oil and related toxicant effects on mallard immune defenses." Environ. Res. 33:343-352.

Snyder, S. B., J. G. Fox, and O. A. Soare. 1973. Mortalities in Waterfowl Following Bunker C Fuel Exposure. Div. Lab. Animal Med., Stanford Med. Ctr. Stanford, 50 pp.

Schuurman, H. J., M.A.M. Krajnc-Franken, C. F. Kuper, H. van Loveren, and J. G. Vos. 1991. "Immune system." In Handbook of Toxicologic Pathology, W. M. Haschek, and C. G. Rousseaux (eds), pp. 421-488. Academic Press, San Diego.

Szaro, R. C., G. Hensler, and G. H. Heinz. 1981. "Effects of chronic ingestion of No.2. Fuel oil on mallard ducklings." J. Toxicol. Environ. Health. 7:789-799.

Tsiagbe, V. K., M.E. Cook, A. E. Harper, and M. L. Sunde. 1987. "Enhanced immune responses in broiler chicks fed methionine-supplemented diets." Poultry Sci. 66:1147-1154.

White, J. 1992. "Protocol for the rehabilitation of oil-affected waterbirds." In Proceedings of the oil spill and wildlife emergency response conference, pp. 1-11. University of California, Davis. 


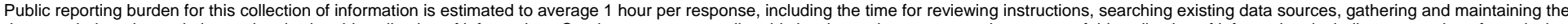

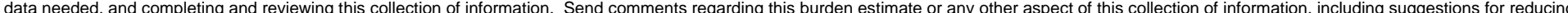

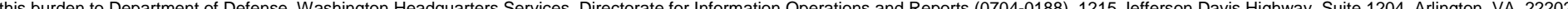

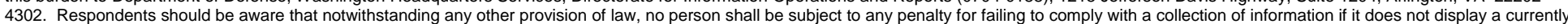
valid OMB control number. PLEASE DO NOT RETURN YOUR FORM TO THE ABOVE ADDRESS.
1. REPORT DATE (DD-MM-YYYY)
09-2004
2. REPORT TYPE

UBTITLE

\section{TITLE AND SUBTITLE}

Effects of Fog Oil Smoke on Immune Responses in the House Sparrow (Passer domesticus) and Red-winged Blackbird (Agelaius phoeniceus)
3. DATES COVERED (From - To)

5a. CONTRACT NUMBER

5b. GRANT NUMBER

5c. PROGRAM ELEMENT NUMBER

5d. PROJECT NUMBER

SERDP

5e. TASK NUMBER

CS-507

5f. WORK UNIT NUMBER

8. PERFORMING ORGANIZATION REPORT NUMBER

ERDC/CERL TR-04-13

U.S. Army Engineer Research and Development Center (ERDC)

Construction Engineering Research Laboratory (CERL)

PO Box 9005

Champaign, IL 61826-9005

\section{SPONSORING I MONITORING AGENCY NAME(S) AND ADDRESS(ES)}

Strategic Environmental Research and Development Program

901 N. Stuart St. Suite 303

Arlington, VA 22203-1821

10. SPONSOR/MONITOR'S ACRONYM(S)

Program Manager

11. SPONSOR/MONITOR'S REPORT NUMBER(S)

12. DISTRIBUTION / AVAILABILITY STATEMENT

Approved for public release; distribution is unlimited.

\section{SUPPLEMENTARY NOTES}

Copies are available from the National Technical Information Service, 5285 Port Royal Road, Springfield, VA 22161.

\section{ABSTRACT}

In response to questions about the effects of military use of fog oil (FO) obscurant smoke, the sensitivity of cell-mediated constituents of the immune system to FO smoke was tested using an avianpox challenge in red-winged blackbirds. Although immunosuppression has been observed in seabirds that have ingested petrochemicals, the immune response in blackbirds exposed to airborne FO was not compromised. The incidence and severity of disease was somewhat less and recovery more advanced in the FO-exposed blackbirds than in controls. Circulating antibody titers to sheep red blood cells were measured in house sparrows by hemagglutination titration. No differences in total, 2-mercaptoethanol-sensitive, or 2-mercaptoethanol-resistant antibody titers were observed, suggesting that humoral immunity is also unaffected by high field-typical FO exposure. Total and differential white blood cell counts were not depressed and spleen mass and structure were not affected in any of the birds exposed to the airborne FO, further indicating that the smoke did not compromise the nonspecific immune function of the birds. No FO-induced mortality, organ pathology, or end point metabolites were observed in either passerine species. These data indicate that the use of FO at normal field concentrations is unlikely to result in decreased immunological fitness of exposed birds.

\section{SUBJECT TERMS}

birds smoke and obscurants risk assessment fog oil military training

\begin{tabular}{|c|c|c|c|c|}
\hline \multicolumn{3}{|c|}{ 16. SECURITY CLASSIFICATION OF: } & \multirow{2}{*}{$\begin{array}{l}\text { 17. LIMITATION } \\
\text { OF ABSTRACT } \\
\text { SAR }\end{array}$} & \multirow{2}{*}{$\begin{array}{l}\text { 18. NUMBER } \\
\text { OF PAGES } \\
32\end{array}$} \\
\hline $\begin{array}{l}\text { a. REPORT } \\
\text { Unclassified }\end{array}$ & $\begin{array}{l}\text { b. ABSTRACT } \\
\text { Unclassified }\end{array}$ & $\begin{array}{l}\text { c. THIS PAGE } \\
\text { Unclassified }\end{array}$ & & \\
\hline
\end{tabular}

19a. NAME OF RESPONSIBLE PERSON 